\title{
Another Kind of R \& R: An Historical Analysis of the Camptown Clean-Up Campaign and the Reinforcement \& Regulation of Camptown Prostitution in South Korea, 1971-1976
}

Shawyn Domyancich-Lee, PhD, MSW, LGSW

Department of Social Work, University of Minnesota, 203 BohH, 1207 Ordean Court, Duluth, MN 55812, United States.

\author{
Article Details \\ Article Type: Commentary Article \\ Received date: $12^{\text {th }}$ November, 2020 \\ Accepted date: $11^{\text {th }}$ December, 2020 \\ Published date: $15^{\text {th }}$ December, 2020
}

"Corresponding Author: Shawyn Domyancich-Lee , PhD, MSW, LGSW, Assistant Professor, Department of Social Work, 203 BohH 1207 Ordean Court, Duluth, MN 55812, United States. E-mail: sclee@d.umn.edu

Citation: Domyancich-Lee, S. (2020). Another Kind of R \& R: An Historical Analysis of the Camptown Clean-Up Campaign and the Reinforcement \& Regulation of Camptown Prostitution in South Korea, 1971-1976. J Ment Health Soc Behav 2(2):126. https://doi.org/10.33790/jmhsb1100126

Copyright: $(2020$, This is an open-access article distributed under the terms of the Creative Commons Attribution License 4.0, which permits unrestricted use, distribution, and reproduction in any medium, provided the original author and source are credited.

\section{Abstract}

This paper analyzes the Camptown Clean-Up Campaign (19711976), a joint governmental initiative between the United States and South Korea to regulate the lives of prostituted South Korean women working in camptowns surrounding U.S. military bases in South Korea. Implemented in large part due to increasing racial tensions between military personnel and Korean nationals, and rising rates of venereal diseases among American soldiers, the Camptown CleanUp Campaign held prostituted women that worked in the camptowns responsible for failing base-community relations. At the same time, national and international laws existed outlawing prostitution and prostitution-related activities. These laws also maintained that parties engaging in prostitution or related activities could be criminally punished. Using the theoretical concept of wartime [1], I argue that the world's understanding of the Cold War as wartime justified this gross breech of national and international law by governments who utilized women and women's bodies to fulfill their own self-interests.

Keywords: Clean-Up Campaign, Cold War, Militarization of Women, Prostitution, Sexual Violence, South Korea, Wartime

\section{Introduction}

Sexual violence against women during times of occupation, war, or conflict has been a pervasive issue throughout history. It is a critical component in the militarization of foreign countries, and subsequently, the people who live there. Feminist scholar Cynthia Enloe [2] stated, "Militarization is a step-by-step process by which a person or a thing gradually comes to be controlled by the military or comes to depend for its well-being on militaristic ideas" (p. 3). She suggested that militarism involves cultural, institutional, ideological, and economic transformations. According to Moon [3], "The power disparities between nations, or governments, have been transferred on to women's bodies, namely that the women of the weaker state represent, through their prostituted bodies, the dominated and controlled position of the weaker state" (p. 141). Militarization also privileges masculinity. Feminist scholars have asserted that "the maintenance of the military establishment depends on promoting gendered notions of femininity and masculinity, weakness and strength, conquered and conqueror" [4]. A military base is a package of presumptions about the male soldier's sexual needs and the local society's resources for satisfying those needs [2].

For centuries, through the militarization of women living in foreign countries, militaries have treated prostitution as both a threat and a resource during times of occupation and conflict. On the one hand, militaries have been threatened with the infiltration of venereal diseases (VDs), for which it was believed the local prostituted women were solely responsible [2]. On the other hand, sexual services from prostituted women contributed to boosting troop morale, as soldiers were far from any kind of female companionship and often suffered under the constant stress of battle [5]. Furthermore, prostitution has played an integral role in shaping foreign policy. The case of U.S. South Korea geopolitics during the 1970s Cold War era has provided an important example of the entanglement of military-regulated prostitution of foreign women and security provision. In the last several decades over a million women have engaged in sex work in service to American servicemen in camptowns located in South Korea [6].

This paper examines the Camptown Clean-up Campaign (hereafter, Clean-up Campaign), implemented in 1971 by the U.S. and South Korean governments as a way to address failing base relations between the American soldiers stationed in South Korea and the sexually victimized women that served them. Using the theoretical concept of wartime, which contemplates the temporality of war, and the resulting impact on societal imagination and expectation, including the justification for sometimes egregious changes to peacetime laws and regulations [1], this paper seeks to answer the question: Why was the Clean-Up Campaign carried out when existing national and international laws during this time period outlawed prostitution and made participating in such activities criminally punishable? In my exploration of answers to this question, I first provide historical background of regulated prostitution by militaries during times of conflict or occupation. I then discuss the Nixon Doctrine and its effects on South Korea and the failing base-community relations that prompted the implementation of the Clean-Up Campaign. Next, I offer an overview of the Clean-Up Campaign, relying heavily on the scholarly work of political scientist Katharine H. S. Moon. Using archival research and interviews with some of the women who were prostituted by the U.S. and Korean governments during the 1970s, Moon is one of the only authors that has written extensively on the topic. This discussion will ensue against the backdrop of 1970s Cold War ideologies and the political climates of both the U.S. and South Korea. Finally, I examine the Clean-Up Campaign within the exceptionality and temporary nature of wartime [1]. I argue that the world understood the Cold War to be a time of war, thus reinforcing and justifying the sexual exploitation 
of women in egregious violations of their human rights, and national and international law by the U.S. and South Korean governments. I suggest that these two countries utilized women and their bodies to fulfill political self-interests as they banded together to prevent the spread of communism.

Before moving into my discussion, I want to provide a note about some of the terminology I will be using. Because this is a historically situated paper, I will use language of the time period. For example, instead of using STI or STD for sexually transmitted infections or sexually transmitted diseases, I will be using the acronym VDs for venereal diseases. Additionally, formal and legal prostitution language referenced in this paper tends to use the terms "forced," or "enforced." I will be using the term "regulated" instead of "forced" or "enforced" in keeping with the language of scholars I will be discussing who have researched and written on the topic. Furthermore, I will be using the term "prostituted," rather than "prostitute," to refer to the women whose activities are regulated by entities in positions of authority or power over them such as pimps, and military and governmental officials. I do this in agreement with Pierce [7], in her study of commercial sexual exploitation of American Indian girls and women, as she writes, "We use the term 'prostituted' rather than 'prostitute' because we find it unreasonable to assign a label to an exploited person that implies that she is responsible for her own exploitation" (p. 20). Similarly, Demleitner [8] cites a definition of forced prostitution as a situation in which victims cannot change their current conditions as prostituted individuals, cannot escape prostitution, and are subjected to sexual violence and exploitation.

\section{Background}

In 1945, as World War II was coming to an end, Korea was decolonized from Japanese rule. From 1945-1948 the U.S. had full military occupation of Korea. By 1949 it had withdrawn the vast majority of its troops from the country leaving only a small contingent of about 500 [9]. The Korean War broke out in 1950, the conflict lasting until 1953 when an armistice was signed, temporarily suspending the fighting and officially establishing a 2.5 -mile-wide demilitarized zone between what is now North and South Korea known as the 38th parallel [10]. To this day a peace treaty has never been signed to officially end the Korean War [11].

After the fighting ceased, South Korea lay in devastated ruins. In addition to deaths numbering nearly 3 million, almost all of South Korea's industries, public facilities, and transportation systems were destroyed. Among those who still remained were approximately 200,000 widows and 100,000 orphans [12]. The 1953 Mutual Defense Treaty established permanent U.S. military bases in South Korea [13]. Camptowns sprung up near these bases, and were essentially manufactured towns that offered the services of clubs, bars, restaurants, and other small businesses to GIs stationed there [14]. Additionally, prostituted South Korean women were employed in the camptown bars and clubs. As the country worked to build some kind of infrastructure after the war ended, it would ultimately be these women who became the binding agents, both economically and politically, between two governments - the United States and Korea. The Korean government saw the twofold benefit of camptowns filled with prostituted women - it would guarantee national security, and earn the highly valued foreign currency that would become a major contributor to Korea's economic success [15]. As Enloe [2] writes, "The prostitution industry had been self-consciously shaped by two governments, each seeking to exert controls that would ensure that its own goals would be met" (p. 91).

South Korea bears a long history of the sexual exploitation of its women. Regulated prostitution in the country dates back to the late 19th century during a political entanglement with Japan. Subsequent Japanese conflicts such as the Sino-Japanese War (1894-1895), the Russo-Japanese War (1904-1905), and World War II (1939-1945) all contributed to regulated systems of prostitution of Korean women by way of pleasure quarters, red light districts, brothels, and comfort stations $[5,16]$. Referred to as comfort women, they were forcefully enslaved by the Japanese Imperial Army during its annexation of Korea. They were made to attend to the sexual needs of soldiers. It was believed that their services helped provide relief from stresses related to combat, and to keep morale high amongst soldiers [5].

Centuries-long practices of sexual violence against women maintained an unconscious acceptability of its certainty during times of warfare and conflict. As a result, our collective gaze has been averted from the plight of foreign women who have, and continue to suffer sexual victimization at the hands of the U.S. military. The case of South Korea is no exception. Ever since the U.S. began its military occupation of the country in 1945, camptown prostitution has existed. Most women prostituted in camp towns during the 1950s, 60s, and 70 s came from poor rural families. Many of them were considered "fallen women," having been cast from their families and society because of divorce, rape, incest, and sex and/or pregnancy before marriage [4]. Some prostituted women had run away from home, escaping abuse. Others had been disowned for deviating from their prescribed gender roles and responsibilities. Recruiters, oftentimes posing as employment agencies, enticed these girls and women into a business of suffering they could never have imagined [17].

\section{0s Cold War Ideologies and Political Climates}

The Cold War marked an unsteady time for Americans as they lived under the constant threat of communism and nuclear warfare. As historian Elaine Tyler May [18] stated, "Containment was the key to security" (p. 16). Containing communism at home and abroad was a fundamental objective of the Cold War. In the 1950s as the Korean War raged on, domestic containment in the U.S. was represented by the formation and maintenance of nuclear families, and white, middle-class standards. Over the next two decades, the Civil Rights Movement and cultural wars of the 1960s and 70s shifted Cold War ideologies from the rigid institutional boundaries of domestic containment to that of strong individualism, risk, and activism [18]. Moreover, the sexual revolution that occurred during the 1960s and 70s led to an increase in VD rates among Americans [19]. In 1972 the federal government began increasing state funding for venereal disease control programs and a national gonorrheacontrol campaign was started [20]. Additionally, during this time assaults were launched upon repressive institutions including the federal government and the armed services. Attitudes reflected disdain for convention, and apprehension about American power, especially pertaining to the Vietnam War [21]. As Small [22] writes, "Polls revealed the growing primacy of domestic over foreign issues and the concomitant public demand for less defense spending" ( $p$. 61). All of this coalesced as the American public descended upon President Nixon and his administration, demanding an end to the war in Vietnam. Additionally, Congress was attempting to regain constitutional balance and mandated that more troops could not be sent abroad without a formal declaration of war [22]. Thus, the Nixon Doctrine was created.

South Korea was also living in fear of the spread of communism from bordering North Korea. Similar to the containment ideologies of 1950s America, in the 70s, South Korea was focused on a kind of containment of its own. Park Chung Hee rose to power in South Korea in 1961 following a coup d'état. The Park regime (1961-1979) sought to modernize the nation through economic development, the establishment of social order and a reformation of humanity, and by building democracy and the welfare state [15]. During the 1950s the U.S. focused itself on the formation and maintenance of the nuclear family. This model of domestic containment established a male breadwinner, and female housewife and caregiver [18]. Twenty years later, in South Korea, the Park regime focused its attention on a similar family model of a male breadwinner and obedient wife and dutiful mother. Women's roles were especially considered as the 
embodiment of nationalism. Either their required virtuousness held them in high esteem as proper figures of South Korean society, or their deviance, as disgraceful as it was, would be regulated and offered to the U.S. military to ensure its continued presence and protection. Moon [3] captured South Korean attitudes toward the expected responsibilities of the prostituted women in the camptowns when she offered a quote from a South Korean government official, who was referencing how Korean prostituted women should behave like Japanese prostituted women:

"The Japanese prostitute, when she finished with the GI, did not get up to go get the next GI (for more money) but knelt before him and pleaded with him to help rebuild Japan. The spirit of the Japanese prostitute spread to the rest of society to develop Japan (p. 154)."

\section{The Nixon Doctrine and Failing Base-Community Relations}

The U.S. military brought a wealth of economic support to struggling post-war South Korea. Camptowns that surrounded U.S. military bases provided jobs for many South Korean nationals who depended on the patronage of American soldiers to keep their businesses running. This included the employment of camptown prostituted women by South Korean bar and club owners. In addition, the military provided a sense of security to a country that very much still felt the threat of war from North Korea. It would be fallout from the Nixon Doctrine that would stir the delicate balance of bilateral relations between South Korea and the U.S.

In her research on the effects of the Nixon Doctrine on U.S.-South Korea foreign relations, Moon [4] summarizes that in response to mounting public pressures at home regarding the Vietnam War, President Nixon and his administration launched the Nixon Doctrine, which essentially called for U.S. disentanglement from Asian conflicts. One of the ways this played out was in the reduction of American troops in Asian countries, thereby transferring the military burden back on to those countries. The rationale of the American government was one that believed that many Asian nations were economically and politically sound enough now to take on increased responsibility for their own security, and needed to rely less on American support and intervention. In President Nixon's speech on "Vietnamization" in 1969, he stated:

"The defense of freedom is everybody's business not just America's business. And it is particularly the responsibility of the people whose freedom is threatened. In the previous administration, we Americanized the war in Vietnam. In this administration, we are Vietnamizing the search for peace [23]".

I contend that "Vietnamizing" could be extended to South Korea in terms of Nixon's administration Koreanizing South Korea's search for peace. In other words, repercussions from the Nixon Doctrine meant that the U.S. felt South Korea was capable of continuing its rebuilding without the need for as much support from the American government and military. More immediately for South Korea this meant a significant reduction of troops stationed in the country. By the end of 1971, the number of troops left in the country decreased from 64,000 since the mid 50s to 43,000 [24]. Remaining troops were re-stationed, wreaking financial havoc among camptown business owners and prostituted women. Many of the business owners and women moved along with the troops, and competition mounted as the locals vied for GI patronage [4].

Although conflicts between base personnel and the broader community were nothing new, the stress of the resulting troop reduction mandated by the Nixon Doctrine seemed to only exacerbate existing tensions. In 1971, base-community problems culminated around racial lines and the discrimination of black soldiers not only by their white counterparts, but also local South Korean bar owners and prostituted women [25]. According to Moon [4], racial discrimination in South Korea's camptowns occurred at a number of different points, and camp town prostituted women were seen as the source of this social problem. They were labeled "black" or "white" depending on which soldiers they serviced. Those labeled "black" were looked down upon by everyone in the camptowns. Additionally, many of the Rest and Relaxation ( $R \& R$ ) establishments were segregated, thus mixing sexual services between all-white and allblack bars and clubs was met with physical violence at the hands of soldiers and bar and club owners who served as pimps. Moon continues by reporting that the discrimination that did occur was often due to economic necessity for the prostituted women, which was informed by racial hierarchy imposed on them by white soldiers, bar and club owners, other prostituted women, and the fact that there were more white soldiers and more white-only bars and clubs.

The early 1970s saw the disintegration of social order along racial lines within camptowns. American government officials had grown increasingly alarmed at the racial hostilities between both black and white soldiers, and black soldiers and South Korean nationals [2]. Additionally, it was clear that people living and working within the camptowns, and American soldiers who frequented the bars and restaurants there felt that the prostituted women were to blame. Furthermore, because the U.S. and South Korean governments relied so heavily on the prostituted women who worked in the camptowns as sexual and diplomatic liaisons between the two countries, they were ultimately held responsible for ensuring that social order be maintained. As racial tensions mounted, the burden of reestablishing that order and ending racial discrimination fell on the women. Acting only within the racist bounds in which they had been indoctrinated, requiring prostituted Korean women to eradicate the racial discrimination in the camptowns was indeed ironic.

\section{The Camptown Clean-Up Campaign}

The Clean-Up Campaign (1971-1976) was an initiative that ultimately emerged out of the Nixon Doctrine to address the failing base-community relations between American soldiers and the Korean nationals occupying the camptowns surrounding U.S. military bases $[4,26]$. The Clean-up Campaign specifically focused its attention on eliminating the racial discrimination of black soldiers and Korean locals, and decreasing venereal disease (VD) rates among American military personnel. In order to do this, the CleanUp Campaign effectively regulated the prostitution of South Korean women, putting the responsibility of ending discrimination and reducing VD rates squarely on them. As Moon [4] states, "During the Clean-Up Campaign, the prostitutes bore the burden of reconciling the differences between two races (blacks and whites) and two governments" (p. 84).

In response to mounting racial tensions in the camptowns, Robert Kinney, the then U.S. Secretary of the Status of Forces Agreement Joint Committee, initiated the Ad Hoc Sub-committee on Civil-Military Relations. Its job was to identify the problems in the camptowns and ensure that any threat to U.S.- South Korea relations would be eliminated [26]. According to Moon [3], at the same time, with South Korea desperately clinging to the U.S. for assured security and protection, it enacted a clean-up policy of its own. The Base-Community Clean-Up Committee (BCCUC) was created by the Blue House (residence of the Korean president) to coordinate and implement clean-up plans. Together, the BCCUC in South Korea and the clean-up initiatives proposed by the U.S. Ad Hoc Subcommittee comprised the Clean-Up Campaign. Collectively, the Clean-Up Campaign coordinated the regulation, education, and medical examinations of camptown prostituted women, with the South Korean government allocating a million dollars during the first two years. From 1971-1976 both the South Korean and American governments conducted investigations and fact-finding tours in order to figure out specific problem areas and solutions for improving base-community relations. The results indicated a need for the prevention of racial discrimination and reduction of VD rates among 


\section{U.S. soldiers $[4,24]$.}

With the responsibility to fix the racial tensions within camptowns and control the spread of VDs among American troops being placed on the prostituted women of the camptowns, these women were held to standards that were often met with further violence and exploitation. Moon's [4] research of the Clean-Up Campaign revealed that in response to racial discrimination the prostituted women were required to attend Etiquette and Good Conduct Meetings in order to learn how to treat black soldiers equally. They were also told how their discriminatory actions helped fuel North Korea's propaganda against the South and the United States. Moon continued by reporting that further pressure was applied to bar and club owners to control their women. In response, many of these owners took advantage of their positions of authority in order to ensure that the prostituted women attended anti-discrimination meetings and were treating black soldiers equally. Physical and psychological abuse was used to subdue women into compliance. Sometimes bar and club owners would confiscate VD cards - required identification cards indicating the women were free of venereal diseases, and without which they were not permitted to work. The cards would be returned once the women completed the Etiquette and Good Conduct Meetings.

Venereal disease rates had grown substantially with the troop reduction and redeployment of the early 70s. Citing statistics from the Eighth U.S. Army of the U.S. Forces Korea (EUSA), Moon [4] reports that in 1972, VD rates among soldiers were 692 cases per 1000 men per year. This was up from 553 in 1971 and 389 in 1970. Monthly VD rates peaked in 1972 at 787 cases per 1000 men per year, and generally averaged 600-700 cases per 1000 men per year. With a high prevalence of VDs among camptown prostituted women (6,700 cases out of approximately 13,000 registered women in 1972), for military authorities, exerting control of the women's bodies, mobility, and treatment for infection were necessary in lowering the rates of VDs among U.S. soldiers.

The spread of VDs posed a serious threat to the troops stationed in South Korea. Infected soldiers would not be able to carry out their duties, and it weakened overall morale. As with the rising racial tensions, prostituted women were blamed for spreading VDs among American soldiers. With the concern over rising VD rates, in 1971, the Clean-Up Campaign pressured the Korean government to begin systematically regulating the bodies, health, and sexual labor of camptown prostituted women. Seen as a "labor of love" for their nation, Moon [4] writes, "With cleaner, healthier bodies and cooperative attitudes in selling sex to GIs, the women would contribute to the defense and development of the Republic of Korea" (p. 92). According to Moon [4], efforts to reduce VD rates among American soldiers were focused primarily on educating and regulating the lives of prostituted women. However, educational trainings were not consistent throughout all of the camptowns both in offerings and content. For example, many times the approach was less concerned with informing the women on how to protect themselves and their health, but more so on the required weekly blood tests and gynecological examinations at the VD clinic. These required examinations led to increased harassment by military police demanding to see VD cards, and women were required to pay for their examinations and treatments. Moon's research continued by asserting that the women were also required to wear tags on their chests that contained their VD card number. If a soldier was to be infected, he needed to remember the number and make a report to medical officials. Since all camptown prostituted women were required to register photos and personal information with military officials, this tagging system was used to crackdown on the source of VDs.

\section{National and International Anti-Prostitution Policies}

With the regulation of sexual violence against Korean women the bilateral relations between the U.S. and South Korea trampled the rights and wellbeing of South Korean women by trading regulated sexual labor for security and economic prosperity. What was particularly troublesome about the Clean-Up Campaign was that it was enacted and carried out even when national and international policies existed at the time that made participating in such activities illegal and punishable by law. For example, in South Korea, The Yullak Prevention Act (1961) defined prostituted women as "abnormal," and specified that all parties involved in prostitution would be punished [15]. Also, about a month prior to the passing of the Yullak Prevention Act, South Korea ratified the U.N. Convention for the Suppression of the Traffic in Persons and of the Exploitation of the Prostitution of Other [15]. The 1950 Convention sought to punish any person involved in the prostitution of another person. Furthermore, it mandated that states repeal any provisions relating to the regulation of prostituted women through such things as registration or supervision of their behaviors [8]. Additionally, in 1966 South Korea ratified the 1949 Fourth Geneva Convention. As referenced in Goldstoff [27], Article 27 of the 1949 Fourth Geneva Convention states that, "Women shall be especially protected against any attack on their honor, in particular against rape, enforced prostitution, or any form of indecent assault" (p. 498). Enforced prostitution is also listed again in Article 75 of Protocol I of the Convention (1977) [28]. However, during the Park Chung Hee regime (1963-1979), there were two major legal provisions that reinforced the necessity of camptown prostitution. The Prostitution Prevention Law was a result in the South Korean government's crackdown on prostitution, but it excluded camptown prostitution. The Tourism Promotion Law designated camptowns as special tourism districts, thereby suggesting that camptown prostitution was needed because it brought in the highly valued American currency [6].

Historians, policy and law analysts, and feminists have begun to examine the issue of the prostitution of South Korean women since the U.S. military established permanent occupation of South Korea in 1953. These scholars have investigated why prostitution, regulated by the U.S. military, persisted. Additionally, they have questioned why this criminal behavior had gone largely unpunished [2-4, 12$14,29,30]$. Following in their footsteps, and in revisiting my initial question of why the Clean-Up Campaign was carried out even though prostitution was illegal, I examine the implementation of the CleanUp Campaign within the theoretical concept of wartime, which, in part, suggests that the temporary nature of wartime warrants exceptions to be made to pre-existing rules [1] and how this justified the Clean-Up Campaign.

\section{Wartime}

The Clean-Up Campaign provides an example of how the U.S. and South Korea militarized South Korean women. Camptown prostitution became one of the only options for "fallen" Korean women who had lost social status within their country for deviating from prescribed gender roles, whether voluntary or coerced. The highly abusive and exploitative prostitution industry provided them employment, some economic support, and housing. However, for the U.S. military it provided morale-boosting and necessary sexual services for young male soldiers in their prime and far away from female companionship. For South Korea, prostitution ensured the continued protection from North Korea. Additionally, it maintained economic support that proved vital to its post-war recovery. Bound up in all of this was the long historical legacy of sexual violence committed against women during times of war, and the legitimation of such acts as a way to guarantee distinction between the "conquered and conqueror." But how was it that, in the case of South Korea, the Clean-Up Campaign, a graphic example of the militarization of women, was allowed to be carried out despite the criminality of engaging in prostitution and prostitution-related activities according to national and international policies? 
In her book, War-Time: An Idea, Its History, Its Consequences, historian Mary Dudziak [1] puts into conversation notions of time and our understandings of what constitutes wartime as opposed to peacetime. The exceptionality of wartime seems to suspend normal political and social functioning because those involved are temporarily held within a state of crises involving threats to individual and collective security. Because wartime (exceptional time) is understood as temporary, and that it will inevitably be followed by peacetime, the use of extreme actions during war is justified. Dudziak [1] writes:

"Wartime is not merely a regulation of the clock; it is the calibration of an era. Once we enter it we expect the rules to change. Some burdens are more tolerable because we think of war as important and exceptional, and also because, by definition, wartime comes to an end (p. 15)."

Kuehnast, de Jonge Oudraat, and Hernes [31] suggest that sexual violence during war is permissible because of the exceptionality of wartime, and that such offenses during war are allowable. Those who perpetrate sexually during war are not considered rapists during the war, or after. The authors liken this to the way that killing during war is justified by the Geneva Conventions, and that soldiers who kill during war are not regarded as murderers either during or after war.

Whether the Cold War was actually a war, since it lacked epic battles of similar caliber to the world wars, has been debated by academics, policy and law analysts, government officials, and historians for years. Citing historian, Odd Arne Westad, Dudziak states, "By the 1950s, the term Cold War came to signal an American concept of warfare against the Soviet Union: aggressive containment without a state of war" (p. 72). Similarly, Dudziak cites Secretary of State Dean Acheson as she writes, "In framing American national security policy, Secretary of State Dean Acheson and others argued that the Cold War was 'in fact a real war,' against a nation that was determined to achieve "world domination"' (p. 70). I also assert that in the minds of many, and certainly within American political attitudes of the 1970 s, the Cold War was indeed a time of war. Therefore, exceptions were justifiably made that defied existing laws designed to outlaw prostitution, including those responsible for victimizing those who became prostituted individuals. Positioning both American soldiers and prostituted South Korean women as agents of national security, a deep divergence emerges. American soldiers became extremely valuable and necessary to the security of South Korea, and therefore, were to be protected. In contrast, the prostituted women of South Korea were commodities to be bought and sold, and configured into living contracts between two governments through the continuous invasion of their bodies.

Moreover, while American troops safeguarded South Korea from the spread of communism, by and large, their actions were also seen as defending the U.S. against communism [1]. The use of prostituted Korean women working in the camptowns was an agreement between both countries in order to fulfill respective political selfinterests. Even though national and international laws and policies existed outlawing prostitution, because of the precarious situation between North and South Korea, America's war against communism, and the anxiety left in the wake of the Nixon Doctrine calling for the reduction of 20,000 troops in South Korea, regulating the lives and bodies of prostituted camptown women was seen as necessary during this exceptional time of war. As Moon [4] writes:

"The sexual domination of tens of thousands of Korean women by 'Yangk'i foreigners' is a social disgrace and a 'necessary evil' that South Koreans believe they have had to endure to keep U.S. soldiers on Korean soil, a compromise in national pride, all for the goal of national security (p. 8)".

\section{Conclusion}

The Camptown Clean-Up Campaign was a policy jointly developed and carried out by both the Korean and U.S. governments to regulate the sexual lives of prostituted Korean women working in camptowns surrounding U.S. military bases during the 1970s. Positioning these women as culprits to both racial tensions and violence that erupted within camptowns, and the spread of venereal diseases among American troops stationed there, government officials enacted the Clean-Up Campaign as a means to reduce VD transmission rates, and to more evenly distribute prostituted Korean women among black and white soldiers [2]. The broader scope of the Clean-up Campaign was containment as the U.S. worked to prevent the spread of communism both domestically and globally. In questioning the legality and ethicality of the Camptown Clean-Up Campaign in light of existing national and international laws outlawing prostitution and related activities, I explored the Clean-up Campaign as an example of how the pervasive masculine culture of the U.S. military dominated the subjugated position of the prostituted Korean women working in the camptowns. Additionally, I examined the Clean-Up Campaign within the theoretical concept of wartime showing how its egregious violations of women's rights and women's bodies was seen as a necessity in the name of national security and economic prosperity, during an exceptional time - wartime - and thereby justified.

Declaration of Competing Interest: The author reports no competing interests.

\section{References}

1. Dudziak, M. L. (2012). War-time: An idea, its history, its consequences. Oxford University Press, Inc.

2. Enloe, C. H. (2000). Maneuvers: The international politics of militarizing women's lives. University of California Press.

3. Moon, K. H. S. (1998). Prostitute bodies and gendered states in U.S.-Korea relations. In E. H. Kim \& C. Choi (Eds.), Dangerous women: Gender and Korean nationalism (pp. 141174). Routledge.

4. Moon, K. H. S. (1997). Sex among allies: Military prostitution in US-Korea relations. Columbia University Press.

5. Hicks, G. (1997). The comfort women: Japan's brutal regime of enforced prostitution in the Second World War. WW Norton \& Company.

6. Lee, J. (2010). Service economies: Militarism, sex work, and migrant labor in South Korea. University of Minnesota Press.

7. Pierce, A. (2009). Shattered hearts: The commercial sexual exploitation of American Indian women and girls in Minnesota. Minnesota Indian Women's Resource Center.

8. Demleitner, N. V. (1994). Forced prostitution: Naming an international offense. Fordham Int'l LJ, 18, 163.

9. Cooley, A. (2008). Base politics: Democratic change and the US military overseas. Cornell University Press.

10. Cumings, B. (2010). The Korean War: A History. Modern Library.

11. Kirk, G., \& Francis, C. B. (2000). Redefining security: Women challenge US Military policy and practice in East Asia. Berkeley Women's LJ, 15, 229.

12. Korean Institute of Military History. (2001). The Korean War. University of Nebraska Press.

13. Moon, K. H. S. (2007). Resurrecting prostitutes and overturning treaties: Gender politics in the" anti-American" movement in South Korea. The Journal of Asian Studies, 129-157.

14. Moon, S. (2010). Camptown prostitution and the imperial SOFA: Abuse and violence against transnational camptown women in South Korea. In M. Höhn, \& S. Moon (Eds.), Over there: Living with the US military empire from World War Two to the present (pp. 337-365). Duke University Press Books. 
15. Park, J. M. (2012, November). Paradoxes of gendering strategy in prostitution policies: South Korea's "toleration-regulation regime," 1961-1979. In Women's Studies International Forum. Pergamon.

16. Soh, C. H. (2004). Women's sexual labor and state in Korean history. Journal of Women's History, 15(4), 170-177.

17. Hughes, D. M., Chon, K. Y., \& Ellerman, D. P. (2007). Modernday comfort women: The US Military, Transnational Crime, and the Trafficking of Women. Violence Against Women, 13(9), 901-922.

18. May, E. T. (2008). Homeward bound: American families in the cold war era. Basic Books.

19. Brandt, A. M. (1985). No magic bullet: A social history of venereal disease in the United States since 1880. Oxford University Press.

20. Henderson, R. H. (1977). Control of sexually transmitted diseases in the United States-A federal perspective. British Journal of Venereal Diseases, 53(4), 211.

21. Bacevich, A. J. (2005). The new American militarism: How Americans are seduced by war. Oxford University Press.

22. Small, M. (1999). The Presidency of Richard Nixon. University Press of Kansas.

23. Nixon, R. (1969). The wars for Viet Nam: President Nixon's speech on "Vietnamization," November 3, 1969. Retrieved from: http://vietnam.vassar.edu/overview/doc14.html.
24. Cheng, S. (2011). The paradox of vernacularization: Women's human rights and the gendering of nationhood. Anthropological Quarterly, 84(2), 475-505.

25. Höhn, M. (2010). The racial crisis of 1971 in the U.S. military: Finding solutions in West Germany and South Korea. In M. Höhn \& S. Moon (Eds.), Over there: Living with the U.S. military empire from World War Two to the present (pp. 311336). Duke University Press.

26. Zimelis, A. (2009). Human rights, the sex industry and foreign troops feminist analysis of nationalism in Japan, South Korea and the Philippines. Cooperation and Conflict, 44(1), 51-71.

27. Goldstoff, M. G. (2009). Security Council Resolution 1820: An imperfect but necessary resolution to protect civilians from rape in war zones. Cardozo JL \& Gender, 16, 491.

28. Kaur, S. (2011). Rape as a war crime. Retrieved from: http:// papers.ssrn.com/sol3/papers.cfm?abstract_id=1802445

29. Kim, E. H., \& Choi, C. (1998). Dangerous women: Gender and Korean nationalism. Routledge.

30. Lee, Y. H. A. (2003). Criminal jurisdiction under the USKorea Status of Forces Agreement: Problems to proposals. $J$. Transnat'l L. \& Pol'y, 13, 213.

31. Kuehnast, K., de Jong Oudraat, C., \& Hernes, H. (Eds.). (2011). Women \& war: Power and protection in the 21st century. United States Institute of Peace. 